\title{
A Global Battlefield? Drones and the Geographical Scope of Armed Conflict
}

\author{
Noam Lubell* \& Nathan Derejko**
}

Forthcoming, Journal of International Criminal Justice, Vol. 11 Issue 1, 2013

\section{Introduction}

Defining the geographical scope of an armed conflict is a matter that carries weight in more ways than one. ${ }^{1}$ Outside the legal sphere the question might seem like one that requires nothing more than common sense - if two (or more) parties are engaged in battle, then the area of conflict is wherever they are fighting. The reality - or at least the legal reality - is unfortunately one that does not conform to simple formulations. Being 'at war' or 'going to war' does not necessarily mean that the whole of a state is in fact embroiled in an armed conflict. For example, while most of Iraq became a zone of armed conflict in 2003, life for most people in the United States continued uninterrupted while its troops invaded a country on the other side of the globe. This can even be the case for both states involved, as was seen in the 1982 Falklands/Malvinas conflict between the UK and Argentina. ${ }^{2}$ The same is true for armed conflicts between a state and an organised armed group, which may be raging in one part of the country with little manifestation in other areas as is evident from the armed conflict between the armed forces of the Philippines and the Moro Islamic Liberation Front (MILF), which, for more than 20 years, was largely confined to the southern island of Mindanao. ${ }^{3}$ Clearly then, the actual hostilities do not necessarily correspond with the borders of the states(s) concerned. Another possibility is to base the determination of geographical scope on the existence of actual fighting. In other words, wherever there are hostilities, there is an armed conflict. But this too has its obstacles, including the question of how to determine what should count as hostilities, and whether there must be a temporal consistency within a specific geographical area that would eliminate occasional flare-ups from the scope. These issues will be returned to in greater detail in later sections.

Our focus is on the particular challenges raised to the geographical scope of armed conflict by the use of unmanned aerial vehicles, commonly referred to as drones. Much has been

\footnotetext{
* Dr Noam Lubell is Reader in the Law of Armed Conflict, School of Law, University of Essex, UK

** Nathan Derejko is Director of the Human Rights Clinic and PhD candidate at the School of Law, University of Essex, UK

${ }^{1}$ Beyond the applicability of $\mathrm{IHL}$, this can also affect matters such as insurance claims, emergency powers under domestic legislation, and subsidiary protection claims.

${ }^{2}$ The fighting was largely confined to the Islands.

${ }^{3}$ ICRC, Our World, Views from the Field: The Philippines, Opinion Survey and In-Depth Research, 2009, 16.
} 
written about drones from a variety of perspectives, ${ }^{4}$ and we do not intend to repeat all the debates. Instead, the aim of this work is to asses not the drones themselves, but rather to examine one of the perceived ways in which the use of drones is affecting, if not leading, to the metamorphosis of armed conflict. The very notion of armed conflict appears to be going through a process of shape-shifting whereby the use of new technologies such as drones or cyber-operations are slowly erasing the crucial significance of geographical boundaries, truncating vast distances, and diminishing the need for boots on the ground.

The ever-increasing use of drones as both a means and method in the pursuit of the 'war on terror' has given rise to concerns over the emergence of a 'global battlefield' whereby the entire planet is subject to the application of the laws of armed conflict and the consequences which flow from it. ${ }^{5}$ These concerns stem from drone strikes frequently occurring outside the 'active battlefields' of Afghanistan and into the border regions of Pakistan and expanding further afield into Yemen and Somalia. Extraterritorial drone strikes against non-state actors have thrust the question of the legal classification and regulation of transnational armed violence to the forefront of international concern and debate. ${ }^{6}$ Three foundational issues are inherent to such classification and regulation. First, there is the question of whether armed violence between a state and a non-state actor occurring in the territory of more than one state can be classified as a non-international armed conflict (NIAC) for the purposes of IHL. Conflicting opinions exist on this issue, with some commentators asserting that the concept of NIAC itself is by definition an internal armed conflict and therefore the scope of $\mathrm{IHL}$ is restricted to the territorial borders of the state experiencing the armed conflict. ${ }^{7}$ Others however, maintain that a NIAC is defined in contradistinction to an international armed conflict (IAC) and therefore any situation of

\footnotetext{
${ }^{4}$ M.N. Schmitt, 'Drone Attacks under the Jus Ad Bellum And Jus in Bello: Clearing the "Fog of Law"', 13 Yearbook of International Humanitarian Law (2010); P. Alston, 'The CIA and Targeted Killings Beyond Borders', 2 Harvard National Security Journal (2011) 283; R. Chesney, 'Who May Be Killed? Anwar al-Awlaki as a Case Study in the International Legal Regulation of Lethal Force', 13 Yearbook of International Humanitarian Law (2010); K. Anderson, "Efficiency" Jus in Bello and "Efficiency" Jus Ad Bellum In the Practice of Targeted Killing Through Drone Warfare?', in C. Finkelstein, J.D. Ohlin, A. Altman (eds), Targeted Killings: Law and Morality in an Asymmetrical World (Oxford University Press, 2012); J. Paust, 'Self-Defense Targeting of Non-State Actors and Permissibility of U.S. Use of Drones in Pakistan', 19 Journal of Transnational Law and Policy (2010) 2; C. Jenks, 'Law from Above: Unmanned Ariel Systems, Use of Force, and the Law of Armed Conflict', 85 North Dakota Law Review (2010) 649; M.E. O'Connell, 'The International Law of Drones', 14 American Society of International Law: Insights 36, 12 Nov. 2010.

${ }^{5}$ See for example, O. Bowcott, 'Drone strikes threaten 50 years of international law, says UN rapporteur', The Guardian, 21 June 2012; J. Mayer, 'The Predator War', The New Yorker, 26 Oct. 2009.

${ }^{6}$ See for example, C. Kreß, 'Some Reflections on the International Legal Framework Governing Transnational Armed Conflicts', 15 Journal of Conflict \& Security Law 2, 2010; P. Alston, Report of the Special Rapporteur on Extrajudicial, Summary or Arbitrary Executions, UN Doc A/HRC 14/24/Add.6, 28 May 2010.
}

\footnotetext{
${ }^{7}$ See for example, Y. Dinstein, 'Concluding Remarks on Non-International Armed Conflicts', in K. Watkin and A.J. Norris (eds), 88 International Law Studies (Blue Book Series), Non-International Armed Conflict in the Twenty-first Century, Naval War College, 2012, 400.
} 
armed violence that amounts to armed conflict, and is not an IAC, is by default a NIAC irrespective of territorial borders. ${ }^{8}$ The key criteria for determining the nature of the conflict in this case, is to be based on the legal status of the opposing parties - a conflict between two or more states is international, while a conflict between a state and a non-state armed group (or between armed groups) is non-international. ${ }^{9}$ For these reasons, and based on more detailed examination elsewhere of the applicable law, ${ }^{10}$ this work proceeds on the premise that international armed conflicts are those between states, while an armed conflict between a state and an organised armed group should be classified as noninternational, even if it includes an extraterritorial manifestation. ${ }^{11}$ The second issue is then the need for determining the geographical scope of applicability of IHL during NIAC. As will be discussed throughout the course of this paper, while no single provision of IHL explicitly delineates its geographical scope, it is the application and interpretation of the individual provisions contained within $\mathrm{IHL}$ that are key to this determination. Although it is uncontested that IHL applies to the conduct of 'battlefield hostilities' between the parties to an armed conflict, the territorial parameters of the battlefield and the range of actions that fall within the remit of hostilities are neither defined in conventional IHL nor beyond debate. The third issue concerns the legal basis for and consequences of, crossing an international border during a prevailing armed conflict between a state and an organised armed group. Here divergent opinions exist as to the circumstances that warrant extraterritorial military operations and the legal implications of such operations, in particular and in relation to the second issue, the geographical scope of applicability of IHL.

This paper will not provide detailed analysis on the threshold of non-international armed conflict; the use of force under public international law; the ethical, political and policy implications of 'targeted killing'; the relationship between IHL and international human rights law; or the legal challenges emerging from unprecedented advancements in military robotics and autonomous weapons systems. While some of these issues will be taken into consideration over the course of the following analysis, the primary focus of this paper is on the legal implications of the geographical disjunction between the location of drone strikes and the primary battlefields for the application of IHL during NIACs of this type.

\section{The geographical scope of non-international armed conflict}

\footnotetext{
${ }^{8}$ See for example, M. Sassoli, 'Use and Abuse of the Laws of War in the "War on Terrorism"', 22 Law and Inequality: A Journal of Theory \& Practice (2004) 195, at 3; S. Sivakumaran, The Law of Non-international Armed Conflict (Oxford University Press, 2012), at 228-35; N. Lubell, Extraterritorial Use of Force Against NonState Actors (Oxford University Press, 2010), at 99-111.

${ }^{9}$ See, L. Zegveld, Accountability of Armed Opposition Groups in International Law (Cambridge University Press, 2002), at 136.

${ }^{10}$ N. Lubell, Extraterritorial Use of Force Against Non-State Actors (Oxford University Press, 2010), at 99-111.

${ }^{11}$ In support see, S. Sivakumaran, The Law of Non-international Armed Conflict (Oxford University Press, 2012), at 228-35.
} 
Conventional international humanitarian law is silent as to the precise geographical scope of international humanitarian law during non-international armed conflict. Both Common Article 3 and Additional Protocol II make explicit reference to the territory of a High Contracting Party when delineating their respective material fields of application, ${ }^{12}$ which may suggest a broad scope of applicability that extends throughout the entire territory of the High Contracting Party where the conflict is occurring. Not unlike the very concept of NIAC itself, developments in international criminal law have provided valuable - albeit on occasion contradictory - material for the attempts in defining the geographical scope of international humanitarian law during NIAC.

According to the Appeals Chamber of the International Criminal Tribunal for the Former Yugoslavia (ICTY), with the emergence of a legally cognizable armed conflict, "international humanitarian law continues to apply in the whole territory of the warring States or, in the case of internal conflicts, the whole territory under the control of a party, whether or not actual combat takes place there." ${ }^{13}$ In contrast to IAC, the Appeals Chamber did not advance an unqualified scope of IHL during NIAC, but clearly restricted its application to the territories under the control of a Party to the conflict. This interpretation confirms the applicability of IHL to territories that are beyond the control of a High Contracting Party and under the control of an organised armed group, a situation envisioned by Additional Protocol II. ${ }^{14}$ At the same time however, it also suggests that any territory potentially outside the control of the Parties to the conflict might not be subject to the application of $\mathrm{IHL}$, irrespective of prevailing hostilities in the territory. A requisite element of territorial control for determining the scope of $\mathrm{IHL}$ is difficult to reconcile with the fact that control over territory is not an indispensible requirement for the existence of a NIAC. ${ }^{15}$ Furthermore, neither the Appeals Chamber nor any subsequent ruling has quantified the nature or degree of control required by a Party to warrant the application of IHL. Such clarification is likely to prove pivotal during an armed conflict between two or more organised armed groups who are fighting for control over a limited portion of a state's territory absent the latter's involvement in the conflict. As will be discussed in the following sections, this formulation is also problematic in cases of extraterritorial NIAC where neither Party can be said to be in control of the territory.

The jurisprudence of the International Criminal Tribunal for Rwanda (ICTR) also offers an interpretation of the geographical scope of $\mathrm{IHL}$ during non-international armed conflict, holding that IHL " ... must be applied to the whole territory of the state engaged in the

\footnotetext{
${ }^{12}$ Article 3, Common to all four Geneva Conventions of 1949; Article 1, Additional Protocol II of 1977.

${ }^{13}$ Prosecutor v. Dusko Tadic, Decision on the Defence Motion for Interlocutory Appeal on Jurisdiction, ICTY, 2 October 1995, § 70.

${ }^{14}$ See Article 1, Additional Protocol II.

${ }^{15}$ Control over territory is however, a necessary precondition for the application of Protocol II. See, Prosecutor v. Boskoski, ICTY Trial Judgment, 10 July 2008, § 197; See also, Prosecutor v Jean-Pierre Bemba Gombo; PreTrial Chamber II Decision Pursuant to Article 61(7)(a) and (b) of the Rome Statute, 15 June 2009, 236.
} 
conflict." ${ }^{16}$ At first sight, the ICTR seems to offer a broader interpretation of the scope of IHL as it abandons the territorial control requirement advanced by the ICTY. Notably however, the ICTR approach necessitates the involvement of a High Contracting Party, applying to the whole territory of the state 'engaged' in the armed conflict. The precise wording of this formulation is problematic as its strict application would seem to preclude the application of IHL during armed conflicts between two or more organised armed groups absent the engagement of any state. Again this is difficult to reconcile with the fact that neither conventional IHL nor existing jurisprudence require state engagement in order to determine the existence of NIAC. ${ }^{17}$ Other Chambers of the ICTR however have taken a slightly nuanced approach, holding that IHL, " ... extends throughout the territory of the State where the hostilities are occurring ..."18 Arguably, this formulation is of further legal value as it dispenses with the requirement of territorial control advanced by the ICTY and the problematic prerequisite of state engagement inherent in the Akayesu judgment of the ICTR. ${ }^{19}$ Focusing on the territory of the state in which the hostilities are occurring, as opposed to the territory of the state(s) engaged in the hostilities, when defining the scope of applicability of $\mathrm{IHL}$, also finds support in national jurisprudence. ${ }^{20}$ Furthermore, the practical utility of such an approach is particularly significant during extraterritorial NIAC where hostilities often occur on the territory of a state not party to the conflict.

The textual inconsistences between these formulations should not be viewed inconsequential, as their resulting scopes of application hold determinative significance when considering the contemporary taxonomy of NIAC. ${ }^{21}$ The common thread that runs through all three formulations, and what is most pertinent to the discussion at hand, is the widely accepted territorial interpretation of the scope of IHL that is independent from the concept of hostilities, and extends to the geographical borders of the relevant state(s). This broad territorial interpretation of the scope of IHL during NIAC is easily and perhaps best understood in terms of the jurisdictional impetus of the criminal tribunals that produced

\footnotetext{
${ }^{16}$ Prosecutor v Akayesu, Trial Chamber Judgment, ICTR-96-4-T, 2 September 1998, § 635-6.

${ }^{17}$ As is evident from the text of common Article 3 and the formulation proposed in Tadic 'or between such groups'. See, Prosecutor v. Dusko Tadic, Decision on the Defence Motion for Interlocutory Appeal on Jurisdiction, ICTY, 2 October 1995, § 70.

${ }^{18}$ Prosecutor v. Rutaganda, Trial Chamber Judgement, ICTR, 6 December 1999, § 101.

${ }^{19}$ See also, Prosecutor v. Bagilishema, Trial Chamber Judgment, ICTR, 7 June 2001, § 101.

20 In the Niyonteze case, the Swiss Military Court of Cassation held that the scope of IHL during noninternational armed conflict includes '... the whole territory of the State in which hostilities are taking place ...'. See, Niyonteze Case, Swiss Military Court of Cassation, as reproduced in M. Sassoli, A.A. Bouvier, A. Quintin (eds), How Does Law Protect in War?, Volume III Cases and Documents ( $3^{\text {rd }}$ Edition 2011), at 2208-2230. For further analysis and specific context of this case see, L. Reydams, 'Niyonteze v. Public Prosecutor', 96 American Journal of International Law (2002) 1.

${ }^{21}$ See M. Milanovic \& V. Hadzi-Vidanovic, A Taxonomy of Armed Conflict, SSRN version, forthcoming in, N. White \& C. Henderson (eds), Research Handbook on International Conflict and Security Law (Edward Elgar, 2012).
} 
them. ${ }^{22}$ The standard line of defence in the ad hoc tribunals has been to deny the very existence of an armed conflict at the exact time and place where the alleged offences were committed. ${ }^{23}$ The absence of an armed conflict negates the concept of a war crime, thereby dissolving the jurisdiction of the Tribunal. However, such jurisdictional issues notwithstanding, the legal value of the unqualified extension of IHL to the geographical borders of the High Contracting Party is a questionable interpretation of the scope of IHL.

Non-international armed conflicts are often circumscribed to comparatively limited and identifiable territories within the states in which they occur. For example, the armed conflict between the Sri Lankan armed forces and Tamil Tigers was largely confined to the Northern and Eastern Regions of Sri Lanka. ${ }^{24}$ The conflict between the armed forces of Uganda and the Lords Resistance Army is largely circumscribed to northern and north-eastern regions of Uganda; ${ }^{25}$ likewise the conflict between the 'Huthis' rebels and the armed forces of Yemen occurred primarily in the most northern region of Yemen; ${ }^{26}$ and the various armed conflicts that have plagued the Democratic Republic of the Congo over the last two decades have all largely occurred within its east and north-east regions. ${ }^{27}$

What these examples highlight is that the existence of a NIAC does not necessarily equate to the entire state as being engulfed in hostilities, a situation that would certainly warrant the pervasive application of IHL. In cases of NIAC where the hostilities are largely constrained to limited territories, it would not only be unnecessary to extend IHL beyond these territories, but could also render IHL vulnerable to abuse. This is particularly relevant during NIAC, which often emerges against the backdrop of internal unrest and widespread violence, and where the shadow of armed conflict and the authority of IHL can be easily exploited to legitimise the otherwise unlawful uses of lethal force against individuals or during situations that are not directly related to the prevailing armed conflict. The existence of a NIAC in a limited portion of a state's overall territory cannot serve as the legal basis for the unqualified application of IHL to any and all situations of civil unrest and violence within that state. Concerns over the unqualified extension of IHL during NIAC were raised during the

\footnotetext{
${ }^{22}$ This is most evident from the jurisdictional scope of the ICTR, which included not only the territory of Rwanda, but also 'the territory of neighboring States', without any degree of specificity as to which neighboring states. See Statute of the International Criminal Tribunal For Rwanda, UN Security Council Resolution 955, 8 November 1994.

${ }^{23}$ Prosecutor v. Dusko Tadic, Decision on the Defence Motion for Interlocutory Appeal on Jurisdiction, ICTY, 2 October 1995, § 66-70.

${ }^{24}$ Particularly the latter end of the conflict, Report of the Secretary-General's Panel of Experts on Accountability on Sri Lanka, United Nations, 31 March 2011, 9-13.

${ }^{25}$ See Annual Report of the United Nations High Commissioner for Human Rights and Reports of the Office of the High Commissioner and the Secretary-General, Addendum - Activities of the Office of the High Commissioner for Human Rights in Uganda, UN Doc. A/HRC/7/38/Add.2, 25 January 2008, at 2,7.

${ }^{26}$ From $2004-2008$ multiple armed conflicts erupted between the 'Huthis; rebels and the armed forces of Yemen in the country's northernmost governorate, Sa'da. See Human Rights Watch, Invisible Civilians: The Challenge of Humanitarian Access in Yemen's Forgotten (2008), at 6.

${ }^{27}$ See, ICRC, Annual Report, Congo, Democratic Republic of the (2011), at 109.
} 
drafting of Protocol II where government experts "considered it inconceivable that, in the case of a disturbance in one specific part of a territory (in a town, for instance) the whole territory of the State should be subjected to the application of the Protocol." 28 It is submitted here that in situations of NIAC where the hostilities are restricted to limited areas, so too should be the application of IHL.

Although indispensible to its effective regulation, IHL is but one piece of the legal puzzle applicable during NIAC. Both national law and international human rights law have equally important roles to play in the regulation of NIAC and its consequences. Therefore, the scope of these legal regimes, and the interplay between them, may also provide insight to the scope of IHL during NIAC. A number of human rights treaties contain a derogation clause allowing states to temporarily adjust certain obligations during situations of public emergency that threaten the life of a nation. What types of situations constitute a 'public emergency' for the purposes of derogation is not beyond debate, although it is generally uncontroversial that a legally cognizable armed conflict would suffice. ${ }^{29}$ Measures of derogations however, are not without restrictions, and must be limited to the extent strictly required by the exigencies of the situation, including its temporal and geographical coverage. ${ }^{30}$ In relation to the unrest and armed violence between the Turkish armed forces and the Kurdistan Workers Party (PKK), Turkey explicitly referenced the provinces that would be subject to measures of derogation, collectively referring to them as the 'state of emergency region' in its derogation notice to the Council of Europe. ${ }^{31}$ The European Court of Human Rights has found Turkey to be in violation of the European Convention on Human Rights when it extended its derogation powers to cities located outside " ... the region where a state of emergency has been proclaimed. ${ }^{\prime 32}$ Restricting emergency legislation and powers to the territory(ies) affected by the emergency creates a balance between the exigencies of a situation and the legal obligations of the state concerned, and a pragmatic precedent for the scope of applicability of IHL.

\footnotetext{
${ }^{28}$ ICRC, Conference of Government Experts on the Reaffirmation and Development of International Humanitarian Law Applicable in Armed Conflicts, Report on the Work of the Conference, Second Session, 3 May - 3 June 1972, Volume I, July 1972, 68, § 2.59.

${ }^{29}$ Indeed, the derogation provisions of both the European Convention on Human Rights and the American Convention on Human Rights refer explicitly to 'in time of war', see Article 15 and 27 respectively. For a discussion on the requirements and process of derogation, see generally, L. Doswald-Beck, Human Rights in Times of Conflict and Terrorism (Oxford University Press, 2011), at 68-105.

${ }^{30}$ General Comment No. 29: States of Emergency (article 4), CCPR/C/21/Rev.1/Add.11, 31 August $2001, \S 4$.

${ }^{31}$ See excerpt of the letter of notification sent by the Permanent Representative of Turkey to the European Council of Europe to the Secretary of the Council of Europe in, Aksoy v Turkey, ECtHR Judgment, Application no. 21987/93, 18 December 1996, § 31 .

${ }^{32}$ As opined by the ECtHR, 'In the present case the Court would be undermining the object and purpose of Article 15, when assessing the territorial scope of the derogation concerned, it were to extend its effects to a part of Turkish territory not explicitly named in the notice of derogation. It follows that the derogation in question is inapplicable ratione loci to the facts of the case.' See Abdulsamet Yaman v Turkey, ECtHR Judgment, Application no. 32446/96, 2 November 2004, § 68-9.
} 
The classification of the situation in Syria in 2012 provides a useful demonstration of this issue. As early as May 2012, the ICRC considered the prevailing situation in Baba Amr in Homs to have met the ICRC's three requisite criteria for NIAC -intensity, duration and organization, while making clear that this factual reality was not uniform throughout the entire country. ${ }^{33}$ While the ICRC explicitly endorsed the existence of a NIAC in Syria, it clarified, "[t]hat does not mean that all areas throughout the country are affected by hostilities. ${ }^{134}$ Initially, the ICRC identified a limited number of areas that were affected by hostilities and thus subject to the application of $\mathrm{IHL}$, but as the conflict intensified and hostilities spread, it acknowledged that other areas had become affected by hostilities and as a result, IHL applies 'wherever hostilities between government forces and opposition groups are taking place across the country. ${ }^{35}$ Of particular significance for the discussion at hand, is the ICRC statement that measures taken outside the areas affected by hostilities, including those against demonstrations with the purpose of restoring law and order, "must respect international law and standards governing the use of force in law enforcement operations." ${ }^{36}$ These comments might be seen as marking a different approach to the longstanding "as wide as possible" position on the scope of Common Article $3 .{ }^{37}$ What is equally clear from the example of Syria, and indeed any armed conflict, is that the concept of NIAC is not static, but rather defined by the factual existence of collective hostilities between the Parties. As hostilities intensify, they are subject to spread and give rise to multiple dislocated areas affected by hostilities, in which the applicability of IHL will incontrovertibly follow.

\section{Moving away from the battlefield}

The appearance of drones in the arsenal of armed conflict has stimulated renewed attempts to define the parameters of the modern battlefield. ${ }^{38}$ The area in which military operations

\footnotetext{
${ }^{33}$ See S. Nebehay, 'Some Syria Violence Amounts to Civil War: Red Cross', Reuters, Geneva, 8 May 2012.

${ }^{34}$ As explained by the ICRC president, Jakob Kellenberger, 'It can be a situation of internal armed conflict in certain areas: an example was the fighting in Baba Amro in Homs in February.' See also S. Nebehay, 'Exclusive: Red Cross ruling raises questions of Syrian war crimes', Reuters, Geneva, 14 July 2012.

${ }^{35}$ See S. Nebehay, 'Exclusive: Red Cross ruling raises questions of Syrian war crimes', Reuters, Geneva, 14 July 2012; see also ICRC Operational Update, Syria: ICRC and Syrian Arab Red Crescent maintain aid effort amid increasing fighting, 17 July 2012.

${ }^{36}$ S. Nebehay, 'Exclusive: Red Cross ruling raises questions of Syrian war crimes', Reuters, Geneva, 14 July 2012.

${ }^{37}$ ICRC Commentary, Article 3, Geneva Convention IV, 36; for the debates surrounding both Syria and the position of the ICRC, see the discussion on the lawfare blog, at http://www.lawfareblog.com/2012/07/thewar-in-syria-and-loac-some-key-issues/.

${ }^{38}$ See for example, L.R. Blank, 'Defining the Battlefield in Contemporary Conflict and Counter-Terrorism: Understanding the §meters of the Zone of Combat', 39 Georgia Journal of International and Comstive Law (2010) 1; K. Anderson, 'Targeted Killing and Drone Warfare: How We Came to Debate Whether There is a "Legal Geography of War"', Washington College of Law Research Paper No. 2011-16, 26 April 2011; M.E. O'Connell, 'Combatants and the Combat Zone', University of Richmond Law Review, forthcoming, Notre Dame Legal Studies Paper No. 08-39, SSRN version, 23 Jan. 2009; J.C. Daskal, 'The Geography of the Battlefield: A
} 
are actually taking place at any given time is known as the 'area of operations' or 'theatre of war', ${ }^{39}$ or simply the 'battlefield'. ${ }^{40}$ Conventional IHL contains references to "zones of military operations", ${ }^{41}$ the 'zone of combat', ${ }^{42}$ and 'battlefield areas' ${ }^{43}$ although does not go as far as to define these terms. ${ }^{44}$ The concept of the battlefield is as unpredictable as it is provisional, and defies static geographical delineation. The codification of the laws of armed conflict throughout the years is testament to this, going back to the provisions of the Lieber Code that apply to the armies 'in the field' and 'along the front' to the provisions of Protocol I that regulate attacks against military objectives that are located in a 'city, town, or village'. ${ }^{45}$ In effect, the concept of a battlefield simply denotes the location in which hostilities are occurring, and its spatial dimensions are shaped and subject to change by the hostilities.

While conventional IHL is replete with references to the concept of hostilities, it does not define the term. ${ }^{46}$ At its most basic, the concept of hostilities refers to "the (collective) resort by the parties to the conflict to means and methods of injuring the enemy." ${ }^{47}$ While it is uncontroversial that hostilities includes attacks, defined as "acts of violence against the adversary, whether in offence or defense" it is generally accepted that is also includes other non-violent acts related to ongoing military operations. ${ }^{48}$ In the context of NIAC, the hostilities (and therefore battlefield) are generally the location where the predicate conditions of "protracted armed violence between governmental authorities and organized armed groups or between such groups" exist at any given time. ${ }^{49}$ While it is uncontested that IHL applies to such hostilities, restricting the application of IHL to the immediate geographical and temporal spheres of hostilities has been explicitly and consistently

Framework for Detention and Targeting Outside the "Hot" Conflict Zone', 161 University of Pennsylvania Law Review (forthcoming 2013), SSRN Version, 1 June 2012.

${ }^{39}$ H. Lauterpacht, Oppenheim's International Law, Vol. II, 237.

${ }^{40}$ See generally, C. Von Clausewitz, On War (Oxford World's Classics, Oxford University Press, 2007).

${ }^{41}$ Article 20, Geneva Convention IV.

${ }^{42}$ Article 5(2)(c), Additional Protocol II; Geneva Convention III employs 'combat zone', 'danger zone' and 'fighting zone' in article 19 alone.

${ }^{43}$ Article 33(4), Additional Protocol II.

${ }^{44}$ Generally speaking, these terms are employed to describe areas in which hostilities are taking place and are used in contradistinction to 'hospital and safety zones', 'neutralized zones' and 'demilitarized zones' that are established to render certain areas immune from hostilities.

${ }^{45}$ In particular, see articles 153 and 136 of the Lieber Code, F. Lieber, Instructions for the Government Armies of the United States in the Field, General Order No. 100 (Washington, Government Printing Office, 1863); see also, article 51(5), Additional Protocol I.

${ }^{46}$ It is generally employed to denote the 'opening of hostilities', 'conduct of hostilities', 'effects of hostilities', 'suspension of hostilities', and 'end of hostilities'.

${ }^{47}$ ICRC, Interpretive Guidance on the Notion of Direct Participation in Hostilities Under International Humanitarian Law (Geneva 2009), at 43.

${ }^{48}$ For a discussion on the concept of hostilities, see N. Melzer, Targeted Killing in International Law (Oxford University Press, 2009), at 269-78; see also Y. Dinstein, The Conduct of Hostilities Under the Law of International Armed Conflict ( $2^{\text {nd }}$ ed, Cambridge University Press, 2010), at 1-2.

${ }^{49}$ Prosecutor v. Dusko Tadic, Decision on the Defence Motion for Interlocutory Appeal on Jurisdiction, ICTY, 2 October 1995, § 70. 
rejected by the ICTY on the grounds that, "[t]here is no necessary correlation between the area where the actual fighting is taking place and the geographical reach of the laws of war. ${ }^{50}$ In addition to and notwithstanding the jurisdictional issues discussed earlier, the extension of IHL beyond the immediate geographical and temporal spheres of hostilities is necessary to prevent attempts by the Parties to an armed conflict to evade the reach of IHL by relocating individuals and directing operations away from the immediate sphere of hostilities. Thus, individuals captured on the battlefield in Afghanistan and detained in Guantanamo Bay cannot be denied the protections of IHL because their detention is geographically and temporally removed from sphere of hostilities in which they were captured. ${ }^{51}$ Furthermore, it is clear that IHL can extend beyond the remit of hostilities to persons 'taking no active part in the hostilities', and 'all persons affected by an armed conflict $^{52}$ and prohibits Parties from establishing places of internment and detention 'close to the combat zone' ${ }^{53}$ In light of all this, how then do we determine the geographical scope of IHL during NIAC beyond the immediate sphere of hostilities?

Reference to developments in international criminal law relating to war crimes can prove instructive as to the scope of IHL beyond the immediate geographical and temporal spheres of hostilities. ${ }^{54}$ The broad territorial interpretation of the scope of IHL advanced by the adhoc tribunals is further calibrated by a 'nexus requirement' for the prosecution of war crimes. The function of the nexus requirement serves to distinguish war crimes from purely domestic crimes and occurrences not directly related to the armed conflict. ${ }^{55}$ In order for an act or omission to qualify as a war crime, it must have been "closely related to the hostilities." ${ }^{156}$ While the modalities governing the operation of the 'nexus requirement' are not instrumental to the discussion at hand, two points merit attention. First, it is clear that the nexus requirement does not demand a strict geographical or temporal proximity to the immediate sphere of hostilities. ${ }^{57}$ Second, the existence of a sufficient nexus is not everlasting but dependent upon the actions of an individual and the relation of those

\footnotetext{
${ }^{50}$ See for example, Prosecutor v Kunarac, ICTY Appeals Judgment, 12 June 2002, § 57.

${ }^{51}$ This issue is se§te from the legality of detention in Guantanamo Bay; for an example of IHL applying outside the primary zone of hostilities in international armed conflict, see the case of military internees in neutral or non-belligerent countries, Geneva Convention III, Article 4(B)(2).

52 See Common Article 3 and Article 2, Additional Protocol II, respectively.

${ }^{53}$ Article 5(2)(c), Additional Protocol II.

${ }^{54}$ In general, war crimes law comprises of the secondary rules to the primary rules of IHL, see, M. Bothe, 'War Crimes', in A. Cassese, P. Gaeta, and J.R.W.D. Jones (eds), The Rome Statute of the International Criminal Court: A Commentary (Oxford University Press, 2002), at 381.

${ }^{55}$ G. Mettraux, International Crimes and the ad hoc Tribunals (Oxford University Press, 2005), at 38-9.

${ }^{56}$ Tadic, ICTY Jurisdiction Decision, § 70; Kunarac, ICTY Trial Judgment, § 402; Krnojelac, ICTY Trial Judgment, § 51.

${ }^{57}$ As confirmed by the ICTY, 'A violation of the laws or customs of war may therefore occur at a time when and in a place where no fighting is actually taking place. As indicated by the Trail Chamber, the requirement that the acts of the accused must be closely related to the armed conflict would no be negated if the crimes were temporally and geographically remote from the actual fighting.' Prosecutor $v$ Kunarac, ICTY Appeals Judgment, 12 June 2002, § 57. See also Kunarac, Trial Judgment, § 568.
} 
actions to the existing armed conflict, and a range of factors exist that may dissolve the nexus between the acts or omissions of the accused and the armed conflict. ${ }^{58}$ The advantage of the 'nexus approach' is that it is not territorially bound, but rather focuses on the link between an individual or conduct and an existing armed conflict. Such an approach to the scope of applicability of IHL is supported by the scope of conventional IHL applicable during NIAC. For example, the provisions of IHL that regulate the internment and detention of individuals, apply only for persons deprived of their liberty for reasons "related to the armed conflict." ${ }^{59}$ Similarly, the provisions on penal prosecutions apply only to the prosecution and punishment of criminal offences "related to the armed conflict." ${ }^{\prime 0}$ The displacement of the civilian population is prohibited under IHL only for "reasons related to the armed conflict." ${ }^{61}$ None of these provisions are geographically bound, but rather require only a relation, or in the words of the ICTY, a nexus to an existing armed conflict. The 'nexus approach' provides a legally tenable avenue to determine the extent to which IHL is applicable outside the immediate geographical spheres of hostilities. Invariably, this approach will require a case-by-case determination and in practice will be dictated by the specific provision or principle of IHL being applied. For example, and as will be discussed in the following sections, determining whether an individual is taking a direct part in hostilities requires the identification of three cumulative criteria; threshold of harm, direct causation, and belligerent nexus, which in practice, can either restrict or expand the application of $\mathrm{IHL}$ to individuals or objects within or beyond the primary sphere of hostilities. ${ }^{62}$

To sum up the discussion thus far, the unqualified extension of IHL to the territorial borders of the state in which a NIAC is prevailing is both unnecessary and potentially dangerous. Restricting IHL to the immediate geographical sphere of hostilities is also problematic not least because it is not clear what acts are included in the remit of hostilities, but also because the provisions of conventional IHL clearly extend beyond such spheres. While the application of IHL to hostilities is both necessary and uncontroversial, its application beyond the primary geographical area of battle must be on the basis of a clear nexus to the prevailing armed conflict, subject to the criteria in the following analysis.

\section{Drone strikes in remote locations}

The possibility of recognising the 'war on terror' or 'war against Al-Qaida' as a distinct and legally cognisable armed conflict is a topic that has been subject to much debate and

\footnotetext{
${ }^{58}$ G. Mettraux, International Crimes and the ad hoc Tribunals (Oxford University Press, 2005), at 47; for a detailed analysis of the nexus requirement see Mettraux at 38-47.

${ }^{59}$ Article 5(1), Additional Protocol II.

${ }^{60}$ Article 6(1), Additional Protocol II.

${ }^{61}$ Article 17, Additional Protocol II.

${ }^{62}$ See ICRC, Interpretive Guidance on the Notion of Direct Participation in Hostilities Under International Humanitarian Law (Geneva, 2009), at 46.
} 
analysis. ${ }^{63}$ For the purpose of our examination there is no need to repeat this debate or agree on an answer to this question. Instead, the main issue at hand is to identify in what circumstances might extraterritorial drone strikes be considered part of an armed conflict, and what are the challenges to making such determinations. Some situations are easier to classify than others, for example drone strikes by the US in areas of Afghanistan in which its military is already operating on the ground and against the same individuals its troops are fighting, would undoubtedly be part of the same armed conflict and subject to IHL. Based on the above analysis of internal NIACs, it can reasonably be argued that drone strikes in more remote areas of Afghanistan in which the US does not have ground troops, against members of the same armed groups, and who are currently taking a direct part in hostilities, could still be part of the same conflict and subject to the application of IHL. Taking this a step further, if the armed group with which the state is already in the midst of an armed conflict has its camp and runs its military operations just across the border in a neighbouring state, and setting aside the possible questions of violating the ius ad bellum, ${ }^{64}$ neither the geographical distance or the crossing of the territorial border would necessarily negate the existence of a nexus between the individuals or their conduct and the prevailing armed conflict. This analysis leads toward a conclusion that could include extraterritorial drone strikes within the scope of IHL. There are however a number of parameters that must be examined before proceeding to such a conclusion. In particular, the analysis might be argued to change when any of the following three elements weaken - although not necessarily break - the nexus between the target and the armed conflict:

i. the geographical distance from the primary sphere of hostilities;

ii. the level and nature of military operations occurring at the target area;

iii. the link between the target and an already occurring armed conflict.

The latter point is a key question in the context of the 'war on terror', as it is not always clear whether the individuals targeted are in fact members of the same organised armed group the US is combating in Afghanistan. ${ }^{65}$ The more tenuous this connection, the more vital it is to see if the first two elements above might nevertheless still lead to the

\footnotetext{
${ }^{63}$ N. Lubell, 'The War (?) Against Al-Qaeda', in E. Wilmshurst (ed), International Law and the Classification of Conflicts (Oxford University Press, 2012); O. Mohamedou, Mohammad-Mahmoud, Non-Linearity of Engagement: Transnational Armed Groups, International Law, and the Conflict between Al Qaeda and the United States, Program on Humanitarian Policy and Conflict Research, Harvard University, 2005; J. Rollins, Al Qaeda and Affiliates: Historical Perspective, Global Presence, and Implications for U.S. Policy, Congressional Research Service Report Prepared for Members and Committees of Congress, 5 February 2010; R. Ingber, 'Untangling Belligerency from Neutrality in the Conflict with al-Qaeda', 47 Texas International Law Journal (2011); C. Kreß, 'Some Reflections on the International Legal Framework Governing Transnational Armed Conflicts', 15 Journal of Conflict \& Security Law 2, 2010.

${ }^{64}$ See section infra, 'The legal effect of crossing borders'.

${ }^{65}$ For example, the Uzbek militant, and members of Pakistani militant groups that are not involved in the fighting in Afghanistan. See generally N. Lubell, 'The War (?) Against Al-Qaeda', in Elizabeth Wilmshurst (ed), International Law and the Classification of Conflicts (Oxford University Press, 2012).
} 
applicability of IHL. This is because in the absence of an ability to encompass the target within the framework of an existing armed conflict, it will become necessary to show that a separate armed conflict exists between the state and the targeted armed group. The difficulty here is that if there is no other fighting elsewhere between members of this armed group and the state, then the only indication for the existence of an armed conflict will be the drone strikes themselves. It is however, highly questionable as to whether a one-sided drone strike can meet the threshold of intensity for armed conflict. ${ }^{66}$ The very concept of armed conflict signifies 'protracted armed violence' between two (or more) Parties, ${ }^{67}$ and drone strikes from the skies with all the attacking done by one side, and all the casualties on the other, hardly fits the bill. Removing this from the drone debates, consider a situation in which state forces turn all of their firepower on a particular group within their borders, with no fighting occurring from the group itself. The state would not fare well in garnering support for a claim that it is in the midst of an armed conflict. In fact, rather than being considered an armed conflict, this would more likely be viewed as a potential case of crimes against humanity. ${ }^{68}$ It is therefore submitted here that drone strikes alone are unlikely to be sufficient for the determination of a NIAC and the ensuing applicability of IHL. The armed group must itself be an active party in the conflict; like a tango, it takes two to war. ${ }^{69}$ Absent the third element of a link with a pre-existing armed conflict, the second element must encompass more than one-sided drone strikes, and include collective hostilities rising to the level of NIAC. Moreover, it requires emphasising that the state carrying out the drone strikes must be party to these hostilities - or acting at the request and jointly with a state which is party to the hostilities - for the drone strikes to be considered part of the armed conflict. However, and notwithstanding the room for further examination of these vexing and highly debatable issues, our current focus is on the first element above: the geographical aspect and how this affects the scope of IHL.

\section{The legal effect of crossing borders}

An earlier section covered the potential applicability of IHL within the territory of a state engaged in a NIAC, and whether this body of law can be assumed to apply throughout the territory of the state or not. An approach of this type is not, however, available in cases of an extraterritorial NIAC. Even in a so-called 'spill-over' conflict, presumably one would not

\footnotetext{
${ }^{66}$ The threshold of NIAC is determined by evaluating the intensity of the armed violence, which includes its duration, (protracted armed violence) and the organisational capacity of the armed groups (organised armed groups) engaged in armed violence. For an analysis of the intensity of violence see, Boskoski, ICTY Trial Judgement, $\S 177$. For a detailed analysis of the organisation requirement, see Limaj, ICTY Trial Judgement, $\S$ 94-134.

${ }^{67}$ In the wording of the ICTY, 'protracted armed violence between Governmental authorities and organized armed groups or between such groups', see Prosecutor v. Dusko Tadic, Decision on the Defence Motion for Interlocutory Appeal on Jurisdiction, ICTY, 2 October 1995, § 70.

${ }^{68}$ Article $7(1)$ of the Rome Statute defines 'crime against humanity' as, ' ... a widespread or systematic attack directed against any civilian population, with knowledge of the attack'.

${ }^{69}$ Although an armed conflict can also involve three or more, unlike the tango.
} 
argue that IHL applies throughout the entirety of the neighbouring State on account of limited military operations chasing rebels across the border. This is even more so in drone strikes occurring in other states and further away from the primary battlefields. Extraterritorial situations emphasise the advantage of a test based on the actual fighting or a clear nexus to it, rather than unqualified application in the whole territory of a state. As will be seen in this section, as central a role as national borders continue to play in the context of the ius ad bellum and any sovereignty related matters, their impact on the applicability of the ius in bello is not of the same magnitude.

The inviolability of state borders is at the heart of the rules on the ius ad bellum. ${ }^{70}$ Other than force used in the exercise of self-defence or with Security Council authorisation, and in accordance with the law regulating these actions, resorting to force across the borders of another state is likely to violate this body of law. ${ }^{71}$ But what bearing does this have on the determination of armed conflict and the applicability of IHL? While the separation of the ius ad bellum and ius in bello has long-standing support and for good reason, that does not mean there is no connection between the two. ${ }^{72}$ In particular, if state A's violation of the ius ad bellum includes or leads to forcible encounters between two states, then an armed conflict will exist and the ius in bello will be applicable. ${ }^{73}$ Likewise if state $A$ invades and occupies a portion of state B's territory, this too could trigger the applicability of $\mathrm{IHL}$ between the two states. Marked differences of opinion can be found, however, when state A uses force on the territory of state $B$, but only against a non-state actor, as can be the case of a drone strike against a militant camp not associated with the state. One approach is that any resort to force on the territory of another state would lead to an IAC between them. ${ }^{74}$ The other position, and the one supported here, holds that - while there may or may not have been a violation of the ius ad bellum - the finding of an IAC between the two states is not an automatic conclusion, and this must be determined on the nature of the force and the context in which it was used. ${ }^{75}$ Not every forcible measure that violates a states'

\footnotetext{
${ }^{70}$ Article 2(4), Charter of the United Nations.

${ }^{71}$ Article 8 bis, of the Rome Statute defines an 'act of aggression' as ' ... the use of armed force by a State against the sovereignty, territorial integrity or political independence of another State, or in any other manner inconsistent with the Charter of the United Nations.' See also United Nations General Assembly Res. 3314 (XXIX) of 14 December 1974.

72 See generally K. Okimoto, The Distinction and Relationship Between Jus ad Bellum and Jus in Bello (Hart Publishing, 2011).

${ }^{73}$ Article 2, common to all four Geneva Conventions of 1949 applies to, 'all cases of declared war or of any other armed conflict which may arise between two or more of the High Contracting Parties, even if the state of war is not recognized by one of them.'

${ }^{74}$ See for example, D. Akande, 'Classification of Armed Conflicts: Relevant Legal Concepts', in E. Wilmshurst (ed), International Law and the Classification of Conflicts (Oxford University Press, 2012).

${ }^{75}$ According to the UK Manual on the Law of Armed Conflict, '[w] hether any particular intervention crosses the threshold so as to become an armed conflict will depend on all the surrounding circumstances. For example, the replacing of border police with soldiers or an accidental border incursion by members of the armed forces would not, in itself, amount to an armed conflict, nor would the accidental bombing of another country. At the other extreme, a full-scale invasion would amount to an armed conflict.' See The Joint Service Manual of the
} 
sovereignty is also an armed conflict between them. There may, for instance, be an armed conflict between state $A$ and the armed group $X$, which does not involve state $B$ despite parts of it occurring on state B's soil. Moreover, forcible operations against a non-state actor on foreign soil can occur outside of any armed conflict: the forcible abduction of Eichmann by Israel from Argentinean territory did not mean that Israel and Argentina were at war, and there was no associated NIAC either. Conversely, in other circumstances there may - in addition to a NIAC between state $A$ and group $X$ - also develop an armed conflict between state $A$ and state $B$, if for example their troops clash, or state $A$ targets state $B$ infrastructure or occupies its territory. ${ }^{76}$ These determinations will be made on a case-by-case basis. Such a finding and classification of any armed conflict will be determined on the basis of the Parties involved, and is a separate matter to the question of whether the ius ad bellum has been violated. The answer to the latter question will very much depend on the position taken with regard to the possibility of self-defence against non-state actors. ${ }^{77}$ This has all been debated at length elsewhere, ${ }^{78}$ and the primary point being noted for our current purpose, is that while the transgression of borders is key for determinations in the ius ad bellum, it is not the key determining factor for the finding of an armed conflict and the applicability of the ius in bello.

The question before us relates to the role played by the location of drone strikes in the determination of the geographical scope of non-international armed conflict. In particular, if state $A$ is engaged in an armed conflict with armed group $X$, does the use of extraterritorial drone strikes against members of $X$ lead to a determination that there is an armed conflict with the ensuing applicability of $\mathrm{IHL}$ - wherever these drone strikes occur? To further separate this question from the above concerns over the ius ad bellum, let us imagine that the drone strike is taking place against the military leadership of armed group $X$ who are directing their operations via satellite radio from a ship on the high seas. No other state's territory (or territorial waters) is being violated, and there is no reason to debate the ius ad bellum in respect of another state. Does IHL apply to this strike? For that to be the case, it would need to be concluded that the drone strike occurred within the context of an armed conflict, a matter that brings us back to the earlier raised issue of the circumstances whereby drone strikes might be considered as such. ${ }^{79}$ As a preliminary point, it should be noted that if IHL could apply to this strike on the high seas, it would be on the basis of an

Law of Armed Conflict, JSP 383 (2004), at 29.

${ }^{76}$ See discussion on the 2006 conflict between Israel and Hezbollah, in N. Lubell, Extraterritorial Use of Force Against Non-State Actors (Oxford University Press, 2010), at 250-4; see also I. Scobbie, 'Lebanon 2006', in E. Wilmshurst (ed), International Law and the Classification of Conflicts (Oxford University Press, 2012).

${ }^{77}$ See N. Lubell, Extraterritorial Use of Force Against Non-State Actors (Oxford University Press, 2010), at 25-

36; see also Y. Dinstein, War, Aggression and Self-Defence ( $5^{\text {th }}$ ed, Cambridge University Press 2011), at 224-7; T. Ruys, 'Armed Attack' and Article 51 of the UN Charter: Evolutions in Customary Law and Practice (Cambridge University Press, 2010), at 419-85.

78 Ibid.

${ }^{79}$ See supra notes 65-66 and accompanying text. 
armed conflict (meeting the requisite intensity and organisational threshold) being found between the state $A$ and the armed group $X$. The fact that it occurred on the high seas does not alter this test. Likewise, if this same strike takes place on the soil of state $B$, the test for IHL applicability does not change; it is a question of determining the existence of an armed conflict between state $A$ and group $X$. If - and this is not a given assumption, but rather a possibility that might only be true in particular circumstances - an armed conflict between them can be found in the context of strikes on the high seas, then one could equally be found when group $X$ is camped in state B. Once again, that is not to render the ius ad bellum irrelevant for other purposes, such as determination of whether state B's sovereignty has been violated, but simply to point out that it is not part of the test as to the existence of an armed conflict between state $A$ and group $X$.

\section{The relevance of distance}

As seen earlier, there may be some debate as to the geographical scope of the armed conflict even when occurring within a single state, and in particular as to whether IHL applies throughout the state or only in specific areas. ${ }^{80}$ But as noted, the geographical spread of conflicts between states and armed groups cannot be 'all or nothing' (or rather 'everywhere or nowhere') immediately applying to the whole territory of any state affected. How then, do we measure and determine the spread of armed conflict and applicability of $I H L$, and does it depend on the distance from the primary battlefield, leading to drone strikes far from the primary battlefield being excluded as not being part of the armed conflict?

The question of distance contains two difficulties. Let us assume for the sake of argument that there is no question that state $A$ and group $X$ are engaged in an armed conflict which takes place in numerous parts of state $A$ itself. Group $X$ then sets up command and training camps just across the border in a remote area of state $B$, and which state $B$ is not sponsoring but is unable to prevent. Group X leaders are based in this camp, their militants are based here and cross the border to carry out attacks before returning to camp, and rockets are even launched from the camp by group $X$ against state $A$ forces. Clearly a nexus exists, and operations by state $A$ against this camp would be considered as part of the armed conflict and governed by IHL. Now let us move this camp from being along the border, inwards to an uninhabited mountainous region of state $B$, three miles from the border. This is unlikely to impact upon the analysis. But what if the mountainous region is ten miles away? fifty? One hundred? Let us assume that other than the distance no parameters have changed; provided all the above facts are still correct, it is unclear why the precise number of miles should affect the applicability of IHL. The second difficulty arises from a comparison between this scenario and a purely internal one: according to some of the earlier discussed

\footnotetext{
${ }^{80}$ See supra 'the geographical scope of non-international armed conflict' notes $12-19$ and accompanying text.
} 
interpretations, a drone strike against armed and active members of group $\mathrm{X}$ holed up in a camp in a remote mountainous region of state $A$ itself would be considered part of the armed conflict, even if this was fifty or one hundred miles away from the main battlefield area where most of the hostilities have been taking place. But if the reason for excluding the extraterritorial operation from the scope of the armed conflict is based on distance from the primary battlefield, why does the same distance-based reasoning not apply in internal situations? The cross-border element certainly affects the ius ad bellum, but other than that the conflict between state $A$ and group $X$ remains the same, as do the other facts set out above. Distance cannot therefore be the primary determinant for the applicability of IHL.

One approach would potentially have any military operation between the state forces and active members of group $X$, seen as part of the armed conflict. To be clear, this approach does not allow for declaring open season on all past or present group $\mathrm{X}$ members around the globe. Neither the battlefield nor the hostilities relocate together with any individual who was on it or previously participating in it; if that were the case, it would be impossible to disengage from an armed conflict. Equally, however, by walking away from the primary combat zone, individuals cannot become immune from attack regardless of their status or the activity in which they engage. If an army general chooses to sit in a building a few miles on the outskirts of the main fighting zone and direct the troops by radio communication from that location, he or she will still be a legitimate target by virtue of their individual status. Likewise, if the individual is a member of an organised armed group and is sitting in a tent or cave a few miles from the main area where fighting is raging, and issuing operational orders by radio to his or her fighters, they too could be a legitimate target for attack - this would be true whether one uses the membership approach, the continuous combat function approach, or most of the various interpretations of direct participation. ${ }^{81}$ Once again, the applicability of the ius in bello does not depend on the number of miles between the individual and the fighters they are commanding and directing, nor does it stand or fall on whether the individual is sitting on one side of a border or the other. The tests are the standard and long-recognised requirements for determining who or what is a legitimate target under $\mathrm{IHL}$, and while they are of course subject to varying interpretations, these interpretations do not change the relative irrelevance of distance or borders. The requirements for the applicability of $\mathrm{IHL}$ are: that an armed conflict is taking place, ${ }^{82}$ and

\footnotetext{
${ }^{81}$ For analysis of these various issues see K. Watkin, 'Opportunity Lost: Organized Armed Groups and the ICRC "Direct Participation in Hostilities" Interpretive Guidance', 42 NYU Journal of International Law and Politics (201) 641; M. Schmitt, 'Deconstructing Direct Participation in Hostilities: The Constitutive Elements', 42 NYU Journal of International Law and Politics (2010) 641; B. Boothby, “And for Such Time As": The Time Dimension to Direct Participation in Hostilities', 42 NYU Journal of International Law and Politics (2010) 641; H. Parks, 'Part IX of the ICRC "Direct Participation in Hostilities" Study: No Mandate, No Expertise, and Legally Incorrect', 42 NYU Journal of International Law and Politics (2010) 641; N. Melzer, 'Keeping the Balance between Military Necessity and Humanity: A Response to Four Critiques of the ICRC's Interpretive Guidance on the Notion of Direct Participation in Hostilities', 42 NYU Journal of International Law and Politics (2010) 641.

${ }^{82}$ See supra notes 65-67 and accompanying text.
} 
that the operations in question are in fact between Parties to this armed conflict (nexus). ${ }^{83}$ The status of the individuals targeted or the attributes of the objects targeted, will then be relevant as to the lawfulness in accordance with IHL (as opposed to its applicability).

As noted, there are a number of areas of debate - factual and legal - and differing interpretations surrounding these issues. First, there may be a question as to the existence of an armed conflict. There must be a specific and identifiable armed conflict between identifiable parties. For example, drone strikes in Afghanistan, or even in Pakistan against militant groups taking part in the Afghan war, are more likely - but far from always - to fulfil this criteria. However, drone strikes in Yemen or Somalia must either be shown to be part of the same armed conflict the US is fighting in Afghanistan, or it must be demonstrated that the US is party to a different armed conflict involving the targets of these strikes (e.g. if acting by request to assist the Yemeni government in their own armed conflict). Second, even if such an armed conflict exists, there may be debates as to whether the targets of the drone strikes are in fact parties to this conflict. For example, the strikes in Pakistan are alleged to have targeted individuals from a wide range of militant groups, not all of whom possess a nexus to the armed conflict in Afghanistan. ${ }^{84}$ If, however, the above criteria are satisfied and $\mathrm{IHL}$ is deemed applicable, there will still remain heavy disagreement as to the correct test for determining which individuals may be targeted.

There have been - and continue to be - heated debates over the rules that apply to targeting individual members of non-state armed groups, and whether their status or certain behaviours preclude them from civilian protection. ${ }^{85}$ Some would apply an approach which deems most members of the group to be legitimate targets, as is the case for most members of a State's armed forces. ${ }^{86}$ Others would resist the analogy to state forces, noting that there is no recognition of a combatant status in NIAC, and would regard these individuals as belonging to the legal category of civilians. ${ }^{87}$ They would then be subject to the rule on loss of protection for such time as they take a direct part in hostilities; the interpretation of "for such time" and "direct participation in hostilities" thereby becomes the centre of controversy. ${ }^{88}$ Finally, a third option was proposed by the ICRC, whereby members of armed groups who carry out a continuous combat function, would cease to be

\footnotetext{
${ }^{83}$ This is one of the weaknesses of the so-called 'war on terror' which seems to have included attacks by the US against militants belonging to groups which are not party to any of the conflicts in which the US is party.

${ }^{84}$ For an analysis of the Conflict in Afghanistan see, F. Hampson, 'Afgahnistan 2001-2010', in E. Wilmshurst (ed), International Law and the Classification of Conflicts (Oxford University Press, 2012).

${ }^{85}$ K. Watkin, 'Opportunity Lost: Organized Armed Groups and the ICRC "Direct Participation in Hostilities" Interpretive Guidance', 42 NYU Journal of International Law and Politics (2010) 641.

${ }^{86}$ See examination and analysis of the various positions in N. Lubell, Extraterritorial Use of Force Against NonState Actors (Oxford University Press, 2010), at 147-155.

87 Ibid.

${ }^{88}$ See discussion in B. Boothby, "'And for Such Time As": The Time Dimension to Direct Participation in Hostilities', 42 NYU Journal of International Law and Politics (201) 641.
} 
civilians and thus not have civilian protection from attack. ${ }^{89}$ While there can be significant implications with major repercussions from adopting one of these interpretations over the others, ${ }^{90}$ for the purpose of examining the geographical scope it is not, however, necessary to agree on which of these interpretations is most appropriate. The direct participation and continuous combat function model will both require some recognition that the targeted individual is engaging in the hostilities; even the wider membership approach will, in practice, likely be used for operations against individuals involved at some level in the combat activities, rather than the camp cooks. All of these will only be relevant if IHL is applicable - which is the issue of concern in the current examination.

An important distinction must be drawn here between the previously discussed nexus to an armed conflict in general for the purposes of war crimes, and the 'belligerent nexus' developed for the purposes of determining direct participation in hostilities. The concept of belligerent nexus was derived and developed on the foundation of the general, although no less requisite, nexus requirement to determine potential war crimes. ${ }^{91}$ However, during the series of expert meetings hosted by the ICRC it was generally agreed that while a general nexus to an armed conflict is necessary for the application of IHL, it is not sufficient for the qualification of a particular act as direct participation in hostilities. ${ }^{92}$ In other words, not every act with a general 'nexus' to an armed conflict automatically qualifies as direct participation in hostilities and results in loss of civilian protection against direct attack. ${ }^{93}$ The concept of belligerent nexus is conceived more narrowly than the general nexus requirement developed in the jurisprudence of the ICTY and ICTR for the qualification of an act or omission as a war crime. ${ }^{94}$ The existence of a belligerent nexus "... presupposes a close relation to not only a pre-existing armed conflict, but also to already on-going hostilities between the Parties to that conflict." ${ }^{95}$ In order to meet the requirement of belligerent nexus, "an act must be specifically designed to directly cause the required threshold of harm in support of a Party to the conflict and to the detriment of another." ${ }^{96}$ of all the controversy surrounding the ICRC guidance on direct participation in hostilities, and

\footnotetext{
${ }^{89}$ ICRC, Interpretive Guidance on the Notion of Direct Participation in Hostilities Under International Humanitarian Law (Geneva 2009), at 33-6.

${ }^{90}$ Some of the differences and implications are, for example, that under the membership approach the nonfighting members might not be civilians to be considered in the proportionality calculations.

${ }^{91}$ See ICRC, Summary Report, Second Expert Meeting on the Notion of Direct Participation in Hostilities, October 2004, The Hague, at 25-26.

92 ICRC, Background Document Working Sessions II and III, Constituent Elements of 'Direct Participation in Hostilities', Expert Meeting on the Notion of Direct Participation in Hostilities Under International Humanitarian Law, 23-25 October 2005, Geneva, at 8.

${ }^{93}$ See ICRC, Summary Report, Third Expert Meeting on the Notion of Direct Participation in Hostilities, Geneva, 23-25 October 2005, at 24.

${ }^{94}$ See ICRC, Interpretive Guidance on the Notion of Direct Participation in Hostilities Under International Humanitarian Law (Geneva 2009), at 58 n. 147.

${ }^{95}$ ICRC, Background Document, Fourth Expert Meeting on the Notion of Direct Participation in Hostilities Under International Humanitarian Law, 27-28 November 2006, Geneva, at 35.

${ }^{96}$ ICRC, Interpretive Guidance on the Notion of Direct Participation in Hostilities Under International Humanitarian Law (Geneva 2009), at 58.
} 
in particular the criticisms of the constituent elements, the 'belligerent nexus' element evoked the least criticism. ${ }^{97}$ For the discussion at hand, it is important to note that the 'belligerent nexus' necessary to determine direct participation in hostilities, while conceived and construed more narrowly than the general nexus to an armed conflict, does not seem to be geographically bound to the primary sphere of hostilities. ${ }^{98}$

The geographical scope becomes relevant to this, insofar as the location of the individual might exclude him/her from being considered as directly participating in the hostilities (or carrying out a continuous combat function). This is particularly relevant during armed conflicts demonstrating substantial asymmetries in both the methods and means of armed conflict, a defining feature of NIAC in general. Indeed, extended geographical distance from the primary battlefield may preclude direct participation in hostilities for Parties with less sophisticated weaponry. ${ }^{99}$ The laws of armed conflict however are predicated on their equal application between the Parties to an armed conflict, and asymmetries of this type will not necessarily influence the scope of IHL. While it might not be as obvious a determination as when assessing the activity of an individual standing in the middle of a battlefield firing a weapon, almost all interpretative models will accept certain activities which do not require physical placement in the firing zone as nevertheless being part of the hostilities. The most obvious of these would be a commander issuing operational directions, but might also arguably include intelligence operations, planning of operations, and more. ${ }^{100}$ The use of drones in the pursuit of hostilities is a prime example of the geographical disjunction between hostilities and direct participation therein. Obviously this is the case with regard to targets of drone attacks in remote areas. It also true however for the other side of the operations: often located thousands of miles from the prevailing hostilities, the drone operators during armed conflict are, as a result of their status or activities, subject to the application of IHL and liable to attack. ${ }^{101}$ In addition, drones often take off and land from a third location that is independent from both the operators controlling them and the hostilities in which they engage. ${ }^{102}$ These 'launch pads' where drones take off or land and

\footnotetext{
${ }^{97}$ Schmitt proposes a disjunctive reading of the two elements inherent to the concept of belligerent nexus, so as 'an act in support or to the detriment of a party.' See M. Schmitt, 'The Interpretive Guidance on the Notion of Direct Participation in Hostilities: A Critical Analysis', 1 Harvard National Security Journal (2010), 27; see also M. Schmitt, 'Deconstructing Direct Participation in Hostilities: The Constituent Elements', 42 NYU Journal of International Law and Politics (2010) 641, at 735-6.

${ }^{98} \mathrm{See}$, for example, the discussion on the measures preparatory to the execution of a specific act of direct participation in hostilities, as well as deployment to and return from the location of its execution. ICRC, Interpretive Guidance on the Notion of Direct Participation in Hostilities Under International Humanitarian Law (Geneva 2009), at 66.

${ }^{99}$ This will very much depend on the interpretation of direct participation in hostilities itself.

${ }^{100}$ For a discussion on what constitutes direct participation in hostilities see, ICRC, Interpretive Guidance on the Notion of Direct Participation in Hostilities Under International Humanitarian Law (Geneva 2009), at 43-58.

101 In support, see Rule 29 of the Manual on International Law Applicable to Air and Missile Warfare, Program on Humanitarian on Humanitarian Policy and Conflict Research, Harvard University, 2009, 15. For context, see E. Bumiller, 'A Day Job Waiting for a Kill Shot a World Away', New York Times, 29 July 2012.

102 These so called 'launch pads' have been documented in Afghanistan, Qatar, United Arab Emirates, Turkey,
} 
are serviced and loaded and re-loaded with munitions, also fall within the remit of legitimate military objectives and would be subject to the application of IHL regardless of their proximity to the hostilities. ${ }^{103}$ This geographical disjunction between direct participation and the actual hostilities is not novel with the advent of drones. Naval personnel who launch missiles from warships located hundreds of miles from their target destination are also directly participating in hostilities despite the fact they can be located hundreds of miles out at sea. Once again, the precise geographical location of the individual is not the determinant factor in the assessment of direct participation in hostilities and the scope of IHL.

From all the above thus far, it becomes apparent that the applicability of the ius in bello is not as geographically bound as may have been assumed. It is not designed to follow state borders and, moreover, while the applicability of IHL revolves around a number of concepts, a hot-zone battlefield is not an indispensable requirement for every operation. There is of course first and foremost, the requirement that there be an armed conflict, without which the ius in bello simply does not apply. In addition to the armed conflict requirement, the other crucial concepts that may allow or restrict targeting operations are those of identifying the parties to the conflict, the notion of hostilities (participation in which can include more than simply firing a weapon), the definition of military objectives, and the status of individuals. Again, as seen earlier, these can all be pertinent to a multitude of situations not limited to the primary battlefield.

\section{Conclusion}

As is evident from the earlier analysis, the unqualified extension of IHL to the whole of the state experiencing an armed conflict is both an unnecessary and potentially dangerous application of $\mathrm{IHL}$. Equally problematic however is restricting the scope of $\mathrm{IHL}$ to the primary geographical sphere of hostilities (the so called 'hot-zone battlefield'), which not only produces counter-intuitive results, but is also not supported by conventional IHL or existing jurisprudence. The application of IHL is dependent upon the existence of an armed conflict, which necessitates the manifestation of hostilities, and IHL regulates those hostilities, wherever they spread. This appreciation however does not endorse the concept of a 'global battlefield' whereby the entire planet is subject to the application of IHL. In assessing

Ethiopia, Djibouti, Seychelles, Yemen. See M. Zenko and E. Welch, 'Where the Drones Are', Foreign Policy, 29 May 2012; see also C. Whitlock and G. Miller, 'U.S. assembling secret drone bases in Africa, Arabian Peninsula, officials say', Washington Post, 21 Sept. 2011.

${ }^{103}$ This issue in particular raises questions about the law of neutrality and its applicability during NIAC. See for example, T. Bridgeman, 'The Law of Neutrality and the Conflict with Al Qaeda', 85 New York University Law Review (2010) 1186. 
whether IHL applies to a particular drone strike, the foundational analytical step is determining the existence of an armed conflict between the state carrying out the strike and the armed group being targeted (general nexus to an armed conflict). In addition, as neither the battlefield nor hostilities necessarily relocate with individuals who were previously on it or engaged in them, it must also be determined that these individuals are in fact directly participating in hostilities and therefore do not enjoy civilian protection from attack (including the requirement of belligerent nexus). Drone strikes do not necessarily extend the battlefield; those that occur against legitimate targets within an already existing conflict are by default occurring in an area to which the conflict participation has already spread. Notwithstanding, there are a number of considerable legal (in addition to policy, ethical and other areas) aspects which will serve to restrict drone strikes. First, in many cases the existence of armed conflict between the striking state and the targeted group can be cast in doubt; nowhere is this clearer than in the so-called global war on terror or war on Al-Qaida (as opposed to the distinct conflict in Afghanistan). The nexus to an existing and identifiable conflict meeting the threshold requirements for classification as such, to which the state and group are Party, must exist; if there is no armed conflict to which the drone strikes are attached, then in most cases the legitimacy for direct lethal strikes will disappear. With no armed conflict, IHL will not apply, and the only remaining framework for regulating force will be that of law enforcement as found in international human rights law, which has a far more restrictive - although not absolutely prohibitive - regulatory approach to lethal force. Second, even if an armed conflict exists, the status of the individuals must be such that renders them to have lost protection under IHL. Third, resorting to force on the territory of another state must also be justified by, and taken in accordance with, the rules of the ius ad bellum. Unless acting with consent of State $B,{ }^{104}$ with UN Security Council authorisation, ${ }^{105}$ or under conditions satisfying the test for action in self-defence, ${ }^{106}$ any such strike would likely be in violation of the ius ad bellum, regardless of its compliance with IHL. It is therefore the ius ad bellum, rather than the ius in bello, which will more often serve as the primary barrier to prevent the precipitous spread of armed conflict to new territories. Finally, the legality of a particular drone strike may also be influenced by the interplay with international human rights law, whether confined to the territory of a single state or extraterritorial. ${ }^{107}$ While in no way beyond debate, human rights law may prove more

\footnotetext{
${ }^{104}$ While it can allow for resort to force in certain circumstances, the issue of consent in relation to use of force is not without its own controversies. For a collection of essays, see P. Alston and E. MacDonald (eds), Human Rights, Intervention and the Use of Force (Oxford University Press, 2008).

${ }^{105}$ Article 39, Charter of the United Nations.

${ }^{106}$ Article 51, Charter of the United Nations; For discussions on the possibility of evoking self-defence against non-state actors see, N. Lubell, Extraterritorial Use of Force Against Non-state Actors (Oxford University Press, 2010), at 25-36; T. Ruys, 'Armed Attack' and Article 51 of the UN Charter: Evolutions in Customary Law and Practice (Cambridge University Press, 2010), at 419 -85; Y. Dinstein, War, Aggression and Self-Defence $\left(5^{\text {th }}\right.$ ed, Cambridge University Press, 2011), at 224-30.

${ }^{107}$ For a detailed analysis of extraterritorial human rights obligations, see N. Lubell, Extraterritorial Use of Force Against Non-State Actors (Oxford University Press, 2010), at chapter 8; see also examination of extraterritorial applicability in M. Milanovic, Extraterritorial Application of Human Rights Treaties: Law, Principles and Policy
} 
influential in its interplay with IHL the further away from the battlefield a drone strike occurs. ${ }^{108}$ Moreover, the lack of transparency regarding the decision making process and the targets, and the scant information from the ground as to the consequences of the strikes, turn any attempt at assessing the legality and seeking accountability into a gruelling task. ${ }^{109}$ Notwithstanding, while all these and other possible rules regulating the force are issues that deserve further attention, the principle focus of this paper was on the geographical scope of applicability of IHL during drone strikes. This analysis has demonstrated that IHL is not in and of itself pre-determined as applying to a limited geographical scope, and its applicability is designed to follow the prevailing hostilities wherever they may spread, rather than vice versa.

(Oxford University Press, 2011); for arguments against, see . Dennis, 'Non-Application of Civil and Political Rights Extraterritorially During Times of International Armed Conflict', 40 Israel Law Review (2007) 2.

${ }^{108}$ For a new approach to the interplay between $\mathrm{IHL}$ and human rights law, allowing for a contextual interpretation based on the circumstances of the case, see N. Prud'homme International Humanitarian Law and International Human Rights Law: From Separation to Complementary Application (draft on file with authors)

${ }^{109}$ For related concerns, see P. Alston, 'The CIA and Targeted Killings Beyond Borders', 2 Harvard National Security Journal (2011) 283; see also For a report on the nature and extent of the effects on civilians see, International Human Rights and Conflict Resolution Clinic (Stanford Law School) and Global Justice Clinic (NYU School of Law), Living Under Drones: Death, Injury and Trauma to Civilians From US Drone Practices in Pakistan, September 2012. 